$\begin{array}{ll}\text { Variants } & \begin{array}{l}\text { Variants } \\ \text { The Journal of the European Society for Textual } \\ \text { Scholarship }\end{array}\end{array}$

$12-13$ | 2016

Varia

\title{
James Turner, Philology: The Forgotten Origins of the Modern Humanities
}

\section{Geert Lernout}

\section{(2) OpenEdition \\ Journals}

Electronic version

URL: http://journals.openedition.org/variants/311

DOI: 10.4000/variants.311

ISSN: 1879-6095

\section{Publisher}

European Society for Textual Scholarship

\section{Printed version}

Date of publication: 31 December 2016

Number of pages: 233-237

ISSN: 1573-3084

\section{Electronic reference}

Geert Lernout, " James Turner, Philology: The Forgotten Origins of the Modern Humanities », Variants [Online], 12-13 | 2016, Online since 01 May 2017, connection on 23 September 2020. URL : http:// journals.openedition.org/variants/311 ; DOI : https://doi.org/10.4000/variants.311

This text was automatically generated on 23 September 2020.

The authors 


\title{
James Turner, Philology: The Forgotten Origins of the Modern Humanities
}

\author{
Geert Lernout
}

\section{REFERENCES}

James Turner. Philology: The Forgotten Origins of the Modern Humanities. Princeton:

Princeton University Press, 2014. 576 pp. ISBN 978-069-114564-8.

1 Before I can review a book with this title, a disclaimer is in order: I may well be one of the few officially accredited philologists left in the world. After my graduation in what in Belgium we still called "Germanic Philology", I was so proud that I had it registered on my new identity card to replace my previous occupation (student). When the official at the Antwerp city hall expressed her doubt that such a word as "philologist" existed and that she could only officially enter it if it was included in her pocket dictionary, I told her, with all my new graduate confidence, "Don't worry, my dear: we make those dictionaries".

2 Since then both the word and what it stands for seem to have disappeared from the face of the earth; most of the philology departments have been renamed and the degrees we still issue are now in "language and literature". Although the word and its derivatives survive in the name of some of the older scholarly journals, the term does not seem to describe a single endeavor. I can only hope that Turner's book will help change that.

Whatever else it is, philology is historical and as such it has always had a not always healthy interest in its own history: in the seventies we even had a first year course on the history of the discipline but in recent years the noun and the adjective seem to have had a bad press since, despite attempts to salvage the term by literary theorists such as Paul de Man and Hans-Ulrich Gumbrecht, these tended to redefine the 
discipline into something that few of its older practitioners would have been able to recognize. Yet de Man's title "The Return of Philology" (1982) has turned out to have been prophetic: all of a sudden, philology is all over the place.

In fact, and this is a second disclaimer: I have been guilty of introducing a term that was later given a decidedly different meaning when I playfully tried to distinguish my own rather old-fashioned work in modern Joyce manuscripts from the more theoretically refined genetic criticism. I was surprised ten years later to see that my term "radical philology" had been adopted in classical studies by Sean Alexander Gurd in order to denote a theoretically sophisticated form of classical scholarship. Since then there are many different compounds, the most recent being "pataphilologist".

In the book under review, James Turner makes large claims for philology as the historical basis for our modern idea of the humanities, which all, with the exception of philosophy, derive from the single discipline that philology still was in the early part of the nineteenth century. Despite the fact that he opens with the statement that the earliest roots of what he also calls "systematic erudition" lie in China and India, this study is restricted to "Western" scholarship, with the story predictably beginning at the library in Alexandria where Eratosthenes of Cyrene was the first person we know who called himself philólogos. This first chapter, ending with the Dark Ages, relies on the standard histories by John Edwin Sandys and Rudolf Pfeiffer, among many others,. Turner's claims are the same as theirs: the Alexandrian critics were pioneers of textual scholarship, creating the first scholarly editions, commentaries, glossaries.

But what he fails to acknowledge is that in a manuscript culture, an "edition" of a Homeric epic, even when it was based on the study of several copies of the text, could only result in the creation of a single document, kept in a single location and as soon as the first copy had been made, the process of variation had started again. In such a context, our current ideas of a standard text are misplaced.

7 Interesting in any case is that Turner devotes more attention to the scholarly study of the bible among Jews and Christians than on the Roman adoption of Greek scholarship, because that is of course where, in and beyond the dark ages, erudition survived, at least in the Christian West. Turner then moves quickly through humanism and the reformation, discussing the contributions of pioneers of philology: Petrarch, Valla, Poliziano, Erasmus, Le Clerc and Bentley, continuing to pay special attention to biblical scholarship, which had a much more active role in this story than historians of classical scholarship usually make room for.

The volume's first part had laid the historical foundations for the discussion in the part II of what the author sees as the fertile ground for the development of the modern humanities in the period between 1800 and the middle of the nineteenth century: the birth of a recognizable form of linguistics, the serious study of literature in the European vernaculars, a new approach to historical studies and, once again, biblical philology. In the third and final part humanist scholarship which until then had been seen as a single endeavor, split up into different disciplines, studied and taught at different departments in the new German-style universities of the second half of the nineteenth century. In the final third part Turner discusses the transformation of these studies into scholarly professions, ending his story roughly with the First World War, more than a century ago.

Needless to say, there were many different ways to tell this story, but Turner has chosen the sensible solution of concentrating on the contributions of a limited number 
of major figures, merely sketching the more general development of intellectual and institutional climate. Despite the bad press that philology has been having, at least since George Eliot's Mr. Casaubon, this long book (nearly four hundred pages in a smallish print) is never boring for anybody with an interest in the ways we can discover and uncover the ways in which our fellow human beings have used and are using language. Every page of this book contains something new and every one of the fifty pages of the book's bibliography contains several items that I had never heard of and, third and final disclaimer, I have been working on an admittedly much less ambitious history of philology for about ten years now that has been preempted by this book.

Turner's story may not end well, but the book makes a strong case for a Whig version of the history of textual scholarship in its widest definition, where the important ingredient is the adjective in what Jean Le Clerc called Ars critica, not criticism, but the critical study of written utterances in the light of everything we know about the writers, their language, historical contexts and the audience they were writing for. Some reviewers have deplored that in this context, it is strange that Turner purposefully excludes philosophy from the humanities: in his epilogue he claims that their presence in humanities at American universities is due to "administrative convenience and accident of timing" (380). Earlier, he had distinguished between the two in terms of philosophy aiming for general truths, whereas philology tries to understand particular utterances.

11 In fact, Turner is quite correct in excluding philosophy, not only for the reasons that he offers in this book. Our current departments of philosophy are the heirs of the theology departments that stood at the core of most universities until the reform in the second half of the nineteenth century. As Turner shows throughout this book, scholars such as Baruch Spinoza and Richard Simon in their study of the bible decided to distinguish between the supposedly general and eternal truths contained in these books and the way these texts could be read critically ("de novo et libero animo", in the words of the former).

12 Although a general survey like this is useful, what I miss is a sense of the nitty-gritty of philological work, which is all over a rival book project, World Philology, edited by Sheldon Pollock, Benjamin A. Elman and Ku-ming Kevin Chang, published by another prominent university press (Harvard University Press, 2015). Part of the difference has to do with the latter editors' ambition to include non-Western traditions of scholarship, but the editors have allowed their contributors to go into detail and to demonstrate in practice the kind of scrutiny that used to be called philological. But this is a small quibble: the different contributions to World Philology only confirm the accuracy of Turner's survey, which is based on an enormous body of materials (fifty pages of bibliography, over twelve hundred titles).

Where does all of this leave philology as a generalist discipline, when the teaching of languages has almost ceased to exist and at a time where there is hardly any time left to learn, let alone practice a discipline of which Nietzsche said it could only be done lento? But maybe Turner does not need to be such a pessimist. As an author of a book on Charles Eliot Norton, he writes that such generalists as the Harvard history professor and social reformer, who translated Dante, edited John Donne's poems and studied medieval church architecture the work of Holbein, would find themselves "in the line at your local unemployment office". His own books, and those of quite a few of the contemporary titles in his bibliography (Anthony Grafton, Frank M. Turner) are proof 
that the academy still has room for a catholicity of diverse and diverging interests. In fact, this summer I read a very long book by the classicist Alan Cameron on the supposed last stand of the pagans against Christianity in late fourth century Rome and this book by the Charles Anthon professor at Columbia University does exactly the kind of wide-ranging critical work on an enormous variety of different kinds of historical and textual materials that Turner discusses in his book. So, despite the fact that I now have to go look for another book project, there is still hope for philology.

\section{AUTHORS}

\section{GEERT LERNOUT}

Geert Lernout teaches English and comparative literature at the University of Antwerp. He has published several books in English on the work of James Joyce and Friedrich Hölderlin and in Dutch on the history of the book, on Bach's Goldberg Variations, on the bible and on the role of religion in the United States. 